\title{
Giambattista Guarini, Il Compendio della poesia tragicomica (De la poésie tragi-comique)
}

\section{Daniela Dalla Valle}

\section{(2) OpenEdition}

1 Journals

\section{Edizione digitale}

URL: http://journals.openedition.org/studifrancesi/7903

DOI: 10.4000/studifrancesi.7903

ISSN: 2421-5856

\section{Editore}

Rosenberg \& Sellier

\section{Edizione cartacea}

Data di pubblicazione: 1 juillet 2009

Paginazione: 389

ISSN: 0039-2944

\section{Notizia bibliografica digitale}

Daniela Dalla Valle, «Giambattista Guarini, II Compendio della poesia tragicomica (De la poésie tragicomique)», Studi Francesi [Online], 158 (LIII | II) | 2009, online dal 30 novembre 2015, consultato il 11 janvier 2021. URL: http://journals.openedition.org/studifrancesi/7903 ; DOI: https://doi.org/10.4000/ studifrancesi.7903

Questo documento è stato generato automaticamente il 11 janvier 2021.

\section{(c) 9 (i) $\Theta$}

Studi Francesi è distribuita con Licenza Creative Commons Attribuzione - Non commerciale - Non opere derivate 4.0 Internazionale. 
Giambattista Guarini, Il Compendio della poesia tragicomica (De la poésie tragi-comique)

Daniela Dalla Valle 


\section{NOTIZIA}

GIAMBATTISTA GUARINI, Il Compendio della poesia tragicomica (De la poésie tragi-comique),

Texte présenté, traduit et annoté par L. GIAVARINI, Paris, Champion, 2008, pp. 416.

1 Il Compendio di Giambattista Guarini è qui presentato e tradotto per la prima volta in francese, accompagnato da una lunga prefazione (p. 170), che si propone di giustificare questa scelta e di illustrarne l'interesse. Il Compendio, infatti, è uno dei testi critici guariniani che costituiscono - come dice la Giavarini - la "querelle du Pastor Fido", tanto diffusa nella Francia del primo Seicento, ed è in questo discorso generale che il testo viene inserito e commentato.

2 L'Introduzione si suddivide in tre parti: «Poétique, ordre social et moeurs polémiques: brève histoire d'une querelle», «L'art poétique de Guarini», «Questions françaises autour de la querelle du Pastor Fido (1610-1637)». Il discorso critico è dunque strettamente comparatista, mescolando e interpretando problemi della letteratura italiana (la prima e la seconda parte) con altri della letteratura francese (la terza parte). La bibliografia utilizzata è ricca, anche se non esaustiva.

La traduzione è stata fatta sull'edizione princeps del 1601, corretta seguendo l'edizione Brognoligo del 1914, che è pubblicata nelle pagine pari. La traduzione è corredata da note, ed è seguita da una Disposition rhétorique du Compendio e da un Index des matières.

Il lavoro di L. Giavarini sarà certamente molto utile a chi si proporrà di lavorare nei prossimi anni sul genere pastorale e sul genere tragicomico nella Francia secentesca. 